929.52 Прстенаров,Д.

Филип Пастенаров (Македонија)

Е-маил: e-mail: filip_pastenarov@yahoo.com

\title{
АНТРОПОЛОШКИ ПОГЛЕД КОН АВТОБИОГРАФИЈАТА НА ДИМИТАР (МИТЕ) ПРСТЕНАРОВ (1913 г. - 1996 г.) ОД СЕЛО ВИШЕНИ, ЕГЕЈСКА МАКЕДОНИЈА
}

Апстракт: Овој труд има за цел да прикаже животна приказна на Македонец од егејскиот дел на Македонија преку обработка на неговата автобиографија, досега зачувана во форма на ракопис. Покрај животната приказна, се прави обид за контекстуализација на воено-политичките настани, општествените и идеолошките околности што се опишани од перспектива на авторот; се прави обид да се согледаат карактеристиките на јазикот и јазичните влијанија што се забележителни во ракописот, а се одраз на живеењето во неколку земји во Источна и Југоисточна Европа.

Клучни зборови: автобиографија, животна приказна, Димитар Прстенаров, партизанство, Егејска Македонија, Вишени, Костурско, комунистичко движење, Втора светска војна, Граѓанска војна во Грција, Демократска армија на Грција, егзодус, социјализам, Македонија, Југославија.

Интересирајќи се за историјата и животот на моите предци, блиски и подалечни, честопати се распрашував кај моите родители, роднини и пријатели, читав литература. Веќе подолго време знаев за материјали што ги имаа оставено моите дедо и баба, за повеќе фотоалбуми, како и за некои ракописи што некогаш ги напишал дедо ми.

Иако знаев за ракописите, никогаш порано немав прилика да ги разгледам, да видам за што се работи. Секогаш поинтересни ми беа албумите, богати со фотографии од животот на мојата фамилија, додека, пак, ракописите беа сметани за помалку важни, а бидејќи се 
напишани со рака, се тешки за читање, па најверојатно никој не беше продолжил да ги чита повеќе од првите страница-две. Тоа што го најдов, што го прочитав, беше воодушевувачки за мене. Ракописите ги сочинуваат материјалите за селото Вишени (Егејска Македонија), кои содржат податоци за историјата на селото, описи на празниците и обичаите, се наведуваат маалата во селото и околните месности, како и многу други податоци поврзани со Вишени и селаните на Вишени, а кои дедо ми, ги објавил во книга за селото Вишени. Другиот дел од ракописните материјали ја сочинуваат автобиографијата на дедо ми Димитар - Мите Прстенаров (1913 - 1996 г.).

Автобиографијата е напишана на рака на деведесет страници. Пишувана е кон крајот на седумдесеттите години на XX век, кога Димитар Прстенаров имал шеесетина години. Најголем дел од речениците се напишани на предната страна од листот, некаде има продолжување на мислата и дополнувања на задната страна од листот, но, исто така, има и додадени (лепени) парчиња хартија со дополнувања, како и дополнување на мислите по страните на веќе пополнетите листови. Во некои случаи додадените (залепените) парчиња хартија требаше да се одлепат за да се прочита дел од ракописот што го беа покриле, и со самото одлепување постоеше опасност вториот слој да се оштети. Сето тоа помина во најдобар ред, но беше потребно многу трпение и внимание. Исто така, постоеја многу оштетени листови, дел скинати и дел каде што ракописот беше размачкан и речиси нечитлив. Некои од листовите беа испомешани, па така беше потребно време за да се најде правилниот редослед. Поради тоа, транскрибирањето и разбирањето на автобиографијата претставуваше навистина голем предизвик.

Напишана е на македонски јазик, на костурски дијалект, но, исто така, можат да се забележат разни јазични влијанија на кои бил подложен авторот во текот на својот живот, како што се: рускиот јазик, литературниот македонски јазик, бугарскиот јазик, српскохрватскиот јазик, како и конструкција на реченици и изрази карактеристични за тогашното југословенско изразување. Исто така, може да се забележат разни варијации на ракописот во којшто постојат делови со читлив и уреден ракопис, како и такви што се нечитливи и хаотични. Сето тоа ни дава слика како за животот на Димитар Прстенаров во историска перспектива така и за Димитар Прстенаров во периодот кога ја пишувал својата автобиографија.

Авторот на биографијата починал во 1996 година, па така ова истражување добива една посебна димензија на истражување на минатото. 


\section{Претставување на себеси и фамилијата}

Димитар Прстенаров, роден на 12.10.1913 г. во селото Вишени - Костурско, бил петтото од шесте деца на Кузо и Каљопа, од кои првото, третото ${ }^{1}$ и последното починале, и не ги познавал.

Пишувајќи за своите родители и за животот и околностите во кои се наоѓале во текот на својот живот, Димитар опишува настани од македонската историја низ раскажувањето на личните случувања на своите родители:

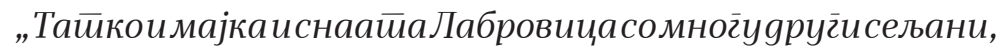
возрасни љуѓe, йайковци, мајки и деgовци беа истиерани

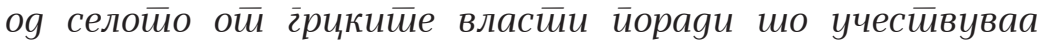

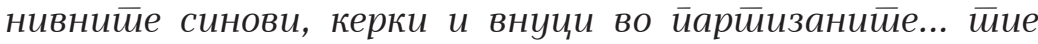

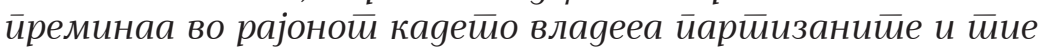
gаgоа својой gойринос во борбайа во йомошнииее служби.

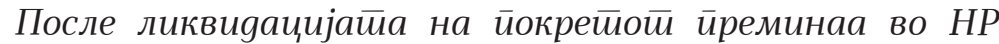
Полска во г̀pag Лечница и во 1960 г̀og. јас г̄и gонесов во Скойје

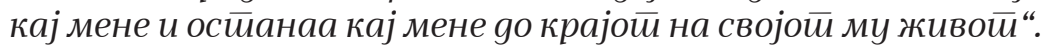

\section{Запознавање со комунистичката идеологија}

Откако започнал да се занимава со шивачкиот занает, Димитар бил во опкружување во коешто силно се негувала комунистичката ${ }^{2}$ идеологија. Така, секојдневно опкружен со идејата за комунизмот, почнал да се интересира за неа. Во шивачкиот дуќан се собирале пријателите на Мајсторот, а помеѓу нив бил и извесен Никос Пападимос, кој бил комунист по идеологија. Честопати Никос го снабдувал Димитар со литература со која подоцна биле запознаени и други негови соселани.

Во1932 година воселото Вишени била оформена комунистичка организација. Таа била сочинета од локалното население, но била под управа на Костурскиот огранок на организацијата.

1 Во ракописот како трето дете го наведува Лабро, но на негово место треба да стои Коле.

2 Терминот „комунистичка“ го користам бидејќ со него се служи Д. П. во автобиографијата, иако всушност станува збор за социјалистичка идеологија и движење. 


\section{Учество на македонската дијаспора во организацијата}

Димитар сведочи за улогата и активностите на брат му Лабро, кој бил отиден на печалба во Канада во 1927 година. Таму тој бил член на горенаведените братства и бил силен поддржувач на „прогресивното движење“" затворан. Лабро имал голем удел во пропагирањето на идеологијата

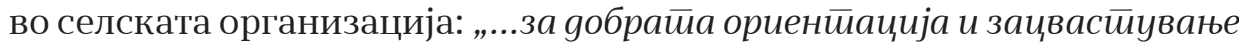

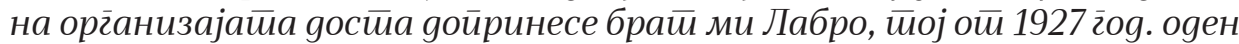

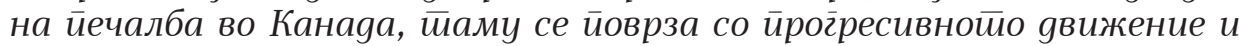

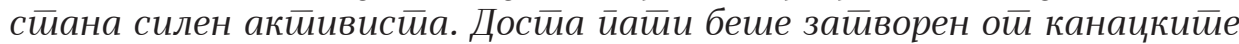

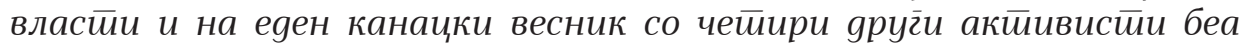

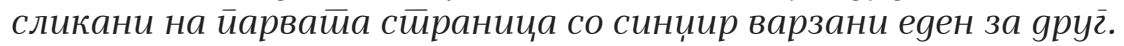

1932 беше дојден за една година, на виде и во то време ни одаржа доста лексии по идејнополитичките вопроси, за нас шо беа многу полезни“ (ДАЕАР, ДЕМ_1530, Автобиографија на Димитар (Мите) Прстенаров).

\section{Периодот на диктатурата на Метаксас}

Пишувајќи во 1938 година, австралискиот автор Берт Биртлс (Bert Birtles) во неговата книга „Егзил во Егејот“ вели: „Ако Грција нема проблеми со Евреи, тогаш таа ги има со Македонците“ (Birtles 1938:131).

Оваа состојба особено дошла до израз за време на диктатурата на Јоанис Метаксас (1936 - 1940) кога репресиите кон Македонците го достигнале можеби својот најбрутален облик.

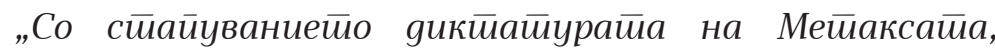

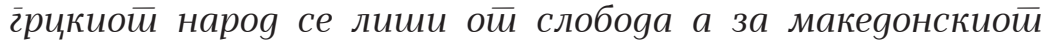
злойо беше gуйло - беше лишен и ой националнииее

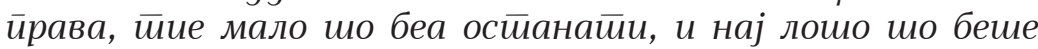
шо со закон му беше забранет̄ gа си говори мајчин му език на макеgонски и кој ке се файваше gа зборва йо

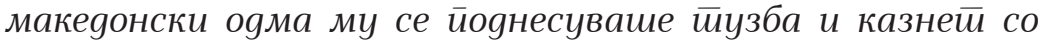
иредвияениой закон 500 gрм $^{5}$ и йола кило рицинусово масло и еgна ренг̃a (солена риба) за gа негіо йоврайи.

3 Термин што го користи Димитар Прстенаров во својата автобиографија во дадениот контекст.

4 Нѐ виде.

5 Драхми. 


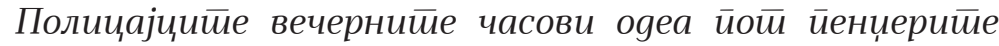

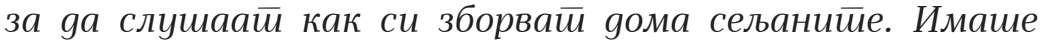
еgен случај, 90 сейа голишна Василица Калкова, баба

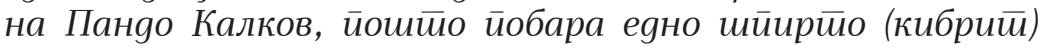

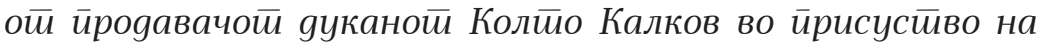

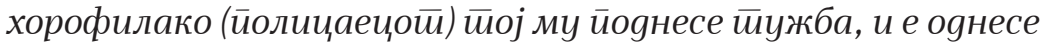
внук му со маикайа gо врайа на суgой заш неможеше gа оgи, а суgијайа е ослобоgи йошйо она не знае Грцки и шо беше мног̄y сииара. (...) Хорофилацийе (иолицајциие) gаже

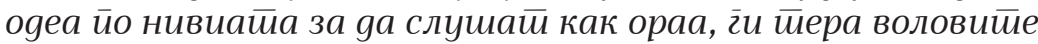

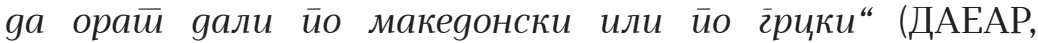
ДЕМ_1530, Автобиографија на Димитар (Мите) Прстенаров).

И покрај тоа што жителите на Вишени и Костурско биле подложени на репресии поради идеолошката и етничката припадност, вишенската комунистичка организација продолжила со своите активности пркосејќи им на сѐ построгите закони и казни.

\section{Форми на отпор}

Прв акт на отпор бил бојкотот на полицијата во селото ${ }^{6}$ како и кон одредени учители што биле „гркомани“. Кулминација на бојкотот се случила за време на празникот „Свети Атанас - Летни“ кога дошло до драстично изолирање на луѓето што биле сметани за „гркомани“ и „шпиони“, при што мнозината луѓе, помеѓу кои биле и членовите на комунистичката организација, одбиле да ги прифатат во селската прослава, односно во заедничкото оро.

Во 1939 година во регионот се случиле навистина турбулентни настани. Албанија била окупирана од страна на фашистичка Италија, а Грција била под константни закани.

За време на овие политички превирања, грчката армија постојано вршела мобилизација на населението. Во редовите на грчката армија повторно стапил Димитар, но по кратко време бил демобилизиран.

Кратко по демобилизацијата стапиле на сцена апсењата на комунистите низ целата грчка држава, па така и во Костурскиот Регион. Се претпоставувало дека комунистичката организација била

6 Од денешна перспектива не може да се добие јасна слика за тоа какво значење имал бојкотот на полицијата, но тоа било драстична мерка, особено бидејќи, сѐ до појавата на немилите настани, полицајците имале сосема нормална интеракција со селаните и повеќе или помалку биле сметани како дел од селската заедница. 
откриена од грчките разузнавачки служби со помош на инфилтрирани агенти во многу ограноци.

За активностите во комунистичката организација сите биле судени и осудени на разни затворски казни. На Димитар му била изречена казна затвор од една година на островот Анафи, но до тоа не дошло бидејќи им било понудено да потпишат „Декларација за откажување од партијата“, а со тоа и да бидат ослободени.

\section{Албанскиот фронт}

Есента 1940 година Димитар бил повторно мобилизиран во грчката армија. Служел во артилериска единица, којашто била стационирана над селото Света Ана на планината Аливица.

По заземањето на Коница, членовите на единицата на Димитар продолжиле пешки сѐ до градот Корча во Албанија каде што биле прераспределени во другите борбени единици.

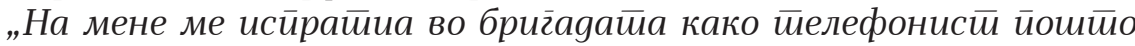

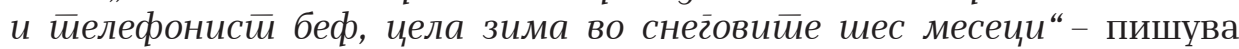
Димитар (ДАЕАР, ДЕМ_1530, Автобиографија на Димитар (Мите) Прстенаров).

Таму останал до месец април 1941 година, сѐ додека единиците на грчката армија не се расформирале по капитулацијата на грчката држава. По сите овие случувања, Димитар повторно се вратил во родното село.

\section{Формирање вооружена организација}

По враќањето во Вишени, Димитар и другите членови на организацијата повторно се активирале сѐ со цел да се организираат во борбата против новите окупатори.

Било одлучено да се почне со вооружување, а во оние села во коишто не постоеле комунистички организации да се воспостават нови.

Со цел фаќање на комунистичката група во која бил и Димитар, од страна на италијанската војска биле спроведени неколку акции. По неколку месеци поминати во бегство, Димитар и уште еден другар од организацијата, Спиро Спасов, решиле да се предадат.

Во почетокот на мај 1942 година заминал прво за Битола, а по 15-ина дена во Софија.

За време на престојот во Софија, Димитар разбрал дека се оформиле партизански групи во Костурско, па поради тоа во почетокот на мај 1943 година се вратил во Вишени. 


\section{Појавата на „контрашки“ организации во Костурско}

По враќањето од Софија, Димитар затекол непријатна состојба во родниот крај. Биле формирани нови вооружени групи, поттикнати и организирани од италијанските и бугарските воени власти.

Организирањето на фашистичките групи, кои Димитар во текстот ги нарекува „контрашки“ или „комитски“, било со цел „Борба йройив Грцийе“ (ДАЕАР, ДЕМ_1530, Автобиографија на Димитар (Мите) Прстенаров), но, исто така, и за борба против „прогресивните“7 комунистички движења.

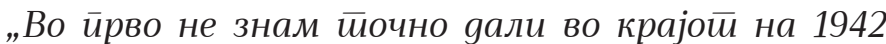

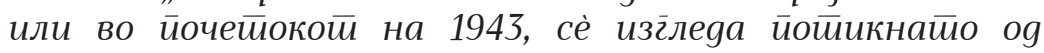

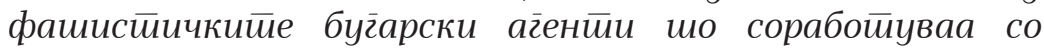

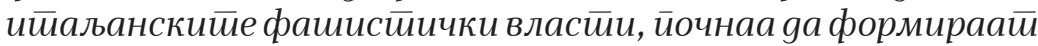

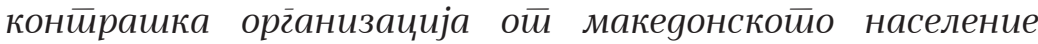

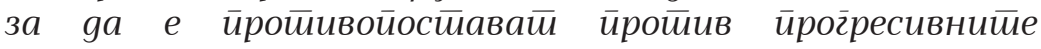

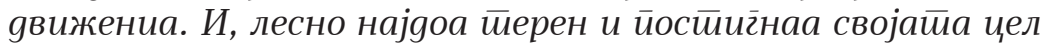

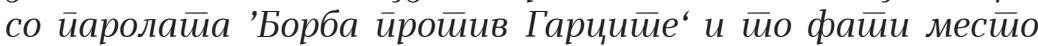
заш макеgонскиой нароg беше цело време беше обесиравен

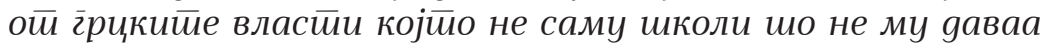

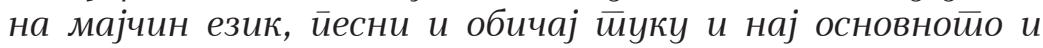
gа му гоо забрани и мајчин му език“ (ДАЕАР, ДЕМ_1530, Автобиографија на Димитар (Мите) Прстенаров).

\section{Засиленото присуство на партизанството}

Во 1943 година партизанското движење се интензивирало во Костурскиот Регион, организирано и поддржано од Комунистичката партија на Грција.

„През исйойо лейо ни гоо йосейи селойо и еgна

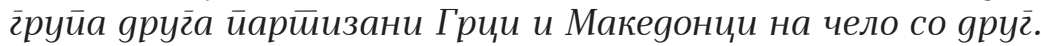

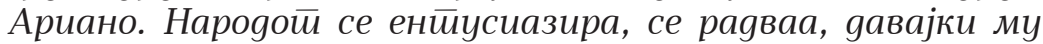

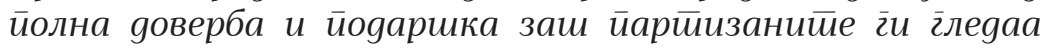

7 Прогресивно движење - термин што Димитар Прстенаров го употребува за именување на комунистичките групи/организации. 


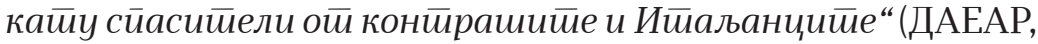
ДЕМ_1530, Автобиографија на Димитар(Мите)Прстенаров).

Истата 1943 година бил оформен одредот „Лазо Трповски“, составен, како што наведува Димитар, „ой йог̄oлем број Смарgешчени, Џуйанишчени, ой Айоскей и ой некој gруг̄u села и со Командир на

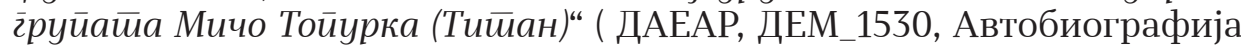
на Димитар (Мите) Прстенаров).

Токму во овој одред Димитар подоцна се приклучил на партизанското движење.

Во истиот период на политичката сцена се случувале одредени несогласувања во КПГ.

Грчкото партиско раководство, во април 1944 година, донело одлука за расформирање на СНОФ и СОВ. Една поголема група Македонци, борци и активисти на ЕЛАС и политички организации, во знак на протест на 16 мај 1944 година се отцепиле од КПГ - ЕЛАС, и, со согласност на ГШ на НОВ и ПОМ, се префрлиле на Караорман каде што се организирале во баталјон, наречен Костурски баталјон.

„Јас си йомисли малко и влијаејки се ой gобриой

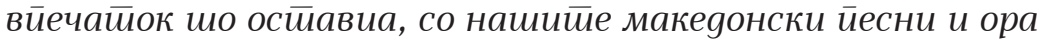
и нај важно макеgонскиой език шо гіо говореа и чарвенайа

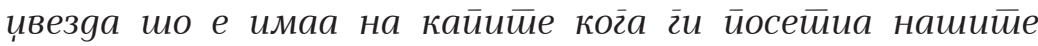

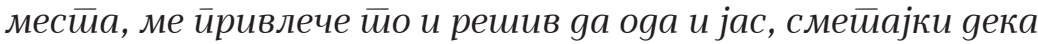
йо е све исйо, борбайа е еgнаква, исииа цел има, без gа ми оgи ни нај малку на ум дека йо ке означи расцейление

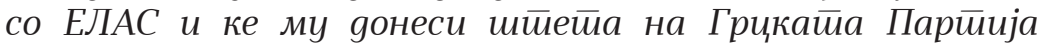
којйо и на мене не ми беше йо кеф“ (ДАЕАР, ДЕМ_1530, Автобиографија на Димитар (Мите) Прстенаров).

Отцепувањето на македонските партизани од редовите на ЕЛАС не било прифатливо за раководството на КПГ. Поради ова прашање биле нарушени и односите помеѓу КПЈ и КПГ.

За овој историски настан сведочи и Димитар во неговата автобиографија:

„При крај на фрйориой месеи, еgен gен не собраа и

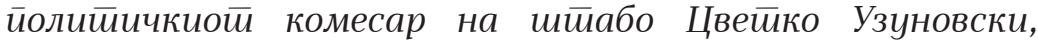
ни одарза говор. Во крайко речено не обеgуваше дека

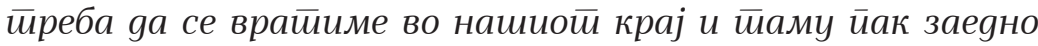

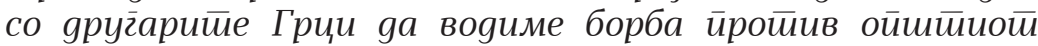

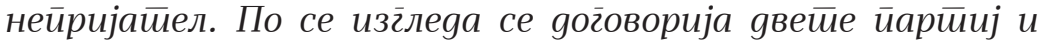

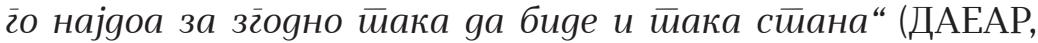
ДЕМ_1530, Автобиографија на Димитар (Мите)Прстенаров).

Во продолжение на ова сведоштво, Димитар го опишува влегувањето на македонските партизани на територијата на Костурскиот Регион и нивното користење на македонски и 
комунистички обележја. Тие биле подоцна забранети и отстранети по наредба на КПГ.

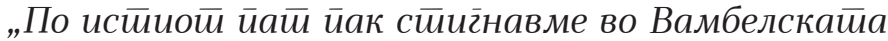
йланина; йаму имаше gве бачила којйо gобро не

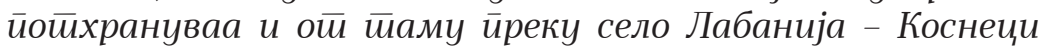

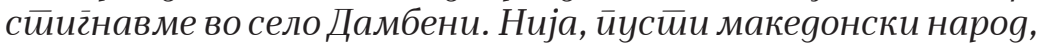
угेнейени, обесирравени, жеgни за нащнонални итрава ${ }^{8}$ ой буржоаскийе йрава на Грција и сегіа мислејки дека г̃о имаме йо йраво, найравивме макеgонско знаме, со иеейокрака

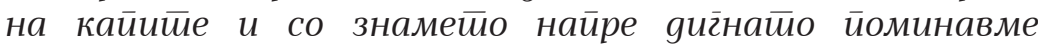

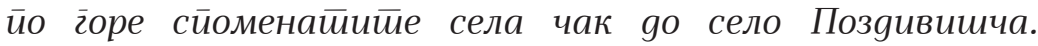

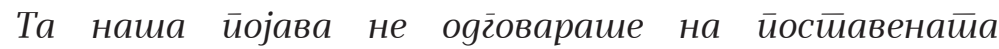

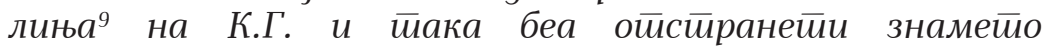

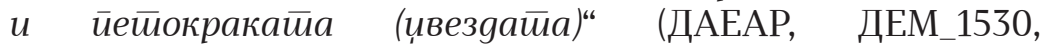
Автобиографија на Димитар (Мите) Прстенаров).

По многубројните превирања на политичко ниво, дошло до одлука македонските единици да се отцепат од составот на ЕЛАС, да бидат префрлени на југословенска територија, во вардарскиот дел на Македонија, и да се стават под команда на ГШ на НОВ и ПОМ.

Според напишаното, Димитар не бил информиран за овие политички случувања, па во автобиографијата тој овие моменти ги запишал од своја перспектива:

„Во нас раяосӣа беше голема, ой еgна сиирана заш

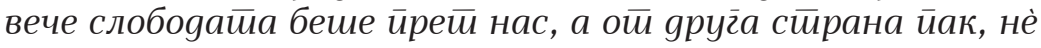

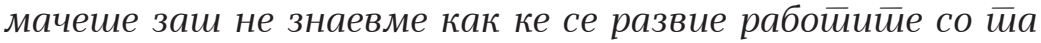
йусйа сйог̄ogба шо е склучиа во Либан йресйавнищи на ПЕА - ЕАМ и имигррацкайа влаgа на Георі̄и Пайандреу. Покрај

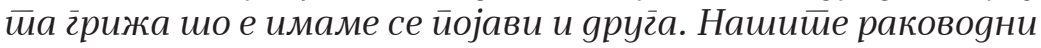
лица gојgоа на неgоразбиране со грцкойо раковосииво. Кој

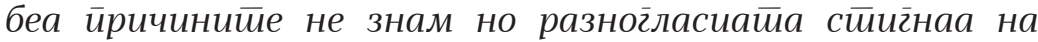

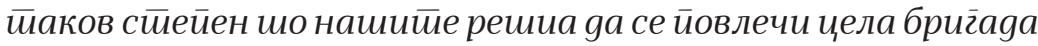

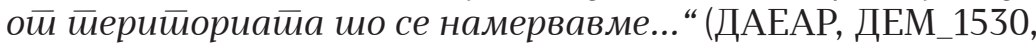
Автобиографија на Димитар (Мите) Прстенаров).

8 Пречкртано.

9 Линија. 


\section{Граѓанската војна во Грција}

По тргнувањето од Битола, групата во која бил Димитар се упатила преку Кајмакчалан ${ }^{10}$ кон селото Попадија. Оттаму, преку Леринско Поле, се упатиле и стигнале во селото Прекопана каде што се наоѓал баталјон чиј водач бил генерал-мајорот Пандо „Ваена“.

До пролетта 1948 година се движеле речиси низ целиот костурски крај водејќи борби со монархофашистите. Оттаму, оставајќи еден баталјон на планината Грамос, продолжиле кон планината Вичо. На тие позиции Димитар останал до април 1948 година, па потоа бил префрлен на позициите на планината Грамос. Од единицата во која бил Димитар, којашто броела 24 луѓе, погинале 13.

Во борбите Димитар бил ранет и лекуван во Албанија. Пролетта 1949 година, повторно заминал на воените позиции на планината Вичо, овој пат во артилериска единица, и таму останал сѐ до повлекувањето на единиците на ДАГ.

\section{Заминувањето во СССР и враќањето во НР Македонија}

Како и повеќето партизани, така и Димитар со својата единица се повлекол на територијата на Албанија, поточно во градот Корча и оттаму во градот Бурел. Во градот Бурел се нашол со неговата жена, која во меѓувреме била во помошните единици на ДАГ, и оттаму заминале за Елбасан за да се видат со родителите на Димитар што биле таму избегани. Од Елбасан се упатиле кон Драч и оттаму со брод биле префрлени во Советскиот Сојуз.

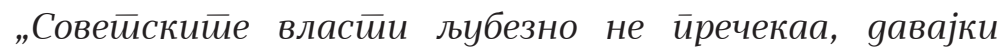
ни сийе удобсиива за живеење. Оше во возо ни имаа на расйолаг̆ање разни музички исйруменйи за разоноgа.

Ког̄а сиичйнавме во г̄раg Чирчик, све ӣрег̄ойвено беше...

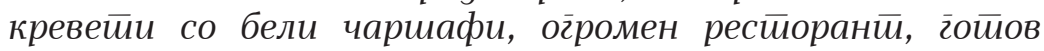
ойремен. Ни gаgоа йо gва йара оgела, еgно официално и еgно

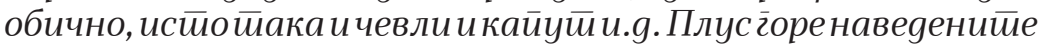
ни gаgоа и йо 500 рубли на секој еgен и йака йродолживме

10 Димитар Прстенаров овој врв во автобиографијата го нарекува Кајмакшалан - Кајмакчалан. 
gа сеgиме и gа јаgиме без gа се йлаќа нешӣо“ (ДАЕАР, ДЕМ_1530, Автобиографија на Димитар (Мите)Прстенаров).

Тој и сопругата најпрво биле вработени во извесен завод ${ }^{11}$, а по 2-3 месеца Димитар бил ангажиран како шивач во шивачка работилница.

По година-две биле преместени во градот Јанѓул, и таму

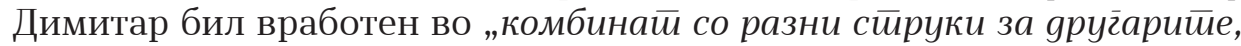
исклучиелно за нас шо беа имвалияи и со слабо зяравие“ (ДАЕАР, ДЕМ_1530, Автобиографија на Димитар (Мите) Прстенаров).

Во комбинатот Димитар бил поставен за раководител на шивачкиот сектор.

По една година повторно биле преместени во „12-то Гратче“12 во близина на Ташкент, коешто било населено единствено со „гарцки политмигранти“13, и тој бил вработен во друг комбинат каде што работеле исклучиво инвалиди и жени со мали деца.

Во тоа населено место останале до 1957 година. За време на престојот во „12-то Гратче“ било одлучено да добијат лични карти. Во личните карти сите иселеници од Егејска Македонија, Македонци и Грци, требало да бидат заведени како Грци, на што мнозинството Македонци се побуниле и побарале да бидат заведени како посебен народ, како Македонци.

„Во йо време ког̄а бевме во 12стио граче се реши gа ни gаgай лични карйи.

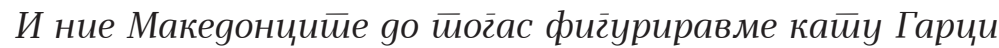
йо име и йрезиме и йо на нас Макеgонциие еио ни ииежеше

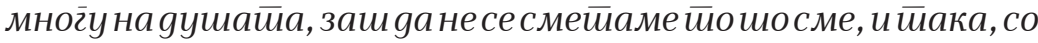

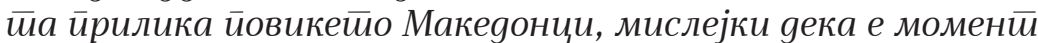
сег̄a и йака се йисаме йо наши Славјанцки назив. Во йо

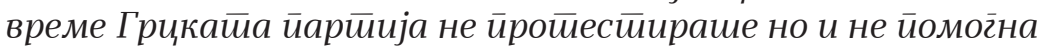

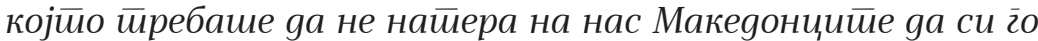
зеваме ирравилнойо, национално име и иррезиме“ (ДАЕАР, ДЕМ_1530, Автобиографија на Димитар (Мите)Прстенаров).

Во месец март 1957 година, дошле во Скопје. На почетокот животот на Димитар и неговото семејство бил доста тежок, но со текот на годините ситуацијата се подобрувала.

Вопоследната реченица од автобиографијата, Димитар пишува дека по дваесет години отишол во пензија и води пензионерски живот.

11 Димитар Прстенаров не наведува дополнителни информации.

12 Не е наведено дополнително објаснување за името на ова место.

13 Во тоа време сите иселеници од Егејска Македонија биле запишани како Грци, состојба што подоцна се променила. 
Димитар Прстенаров починал во Скопје на 6 ноември 1996 година.

\section{Заклучок}

Димитар Прстенаров е роден во 1913 година во село Вишени - Костурска Околија и во текот на својот живот доживеал и бил дел од неколку настани значајни за регионалната, македонската, па и за европската историја. Во автобиографијата Димитар најпрво говори за своето семејство, ги набројува роднините од таткова и мајчина страна и продолжува со раскажување на својот живот, т.е. на својата младост.

Тој целиот свој живот го поминал како поддржувач на идејата за „комунизмот“ и, како таков, во својата автобиографија фокусот го насочува токму кон политичките случувања од времето на неговата младост и неговиот политички активизам во родното место.

Така, Димитар го опишува неговото запознавање со комунистичката идеологија, нејзиното ширење во селото и околината, воспоставувањето организирани групи луѓе врз основа на комунистичката идеологија. Раскажува за разни случувања, пријатни и непријатни. Ја опишува положбата на Македонците и репресиите кон нив, неговото судење и издржување на казната на еден од грчките острови, почетокот на Втората светска војна, неговата мобилизација во грчката војска, за Грчко-италијанската војна, за Албанскиот фронт, за капитулацијата на Грција. Понатаму, пишува за случувањата во селото и регионот за време на италијанската окупација, за појавата на профашистичките „контрашки/комитски“ групи составени од локалното македонско население, а со тоа и за поделбата на населението според политичко и идеолошко убедување. Раскажува за разни немили настани, за организирањето на „комунистичките групи“ против „фашистичките групи“. Опишува многу настани, убиства, битки; раскажува за неговото стапување во партизанските единици и за настани поврзани со партизанството. Го опишува падот на фашизмот и уништувањето на профашистичките организации во Костурскиот Регион, повторната промена на светската и регионалната политика и преминувањето на партизанството во илегала во новата грчка држава, префрлањето на неговата партизанска единица во Југославија, тамошното ангажирање во изградбата на локалната инфраструктура.

Понатаму го опишува почетокот на Граѓанската војна во Грција, неговото враќање во својот крај во Егејска Македонија и неговото учество во Демократската армија на Грција. 
По поразот на ДАГ раскажува за иселувањето од родното место, прво во Албанија, па во Советскиот Сојуз, за тамошниот живот, па сѐ до доаѓањето во НР Македонија.

Така, Димитар Прстенаров, раскажувајќи за својот живот, всушност ни раскажува дел од историјата почувствувана врз себе, ни ги доловува „од прва рака“ случувањата што ги доживеал.
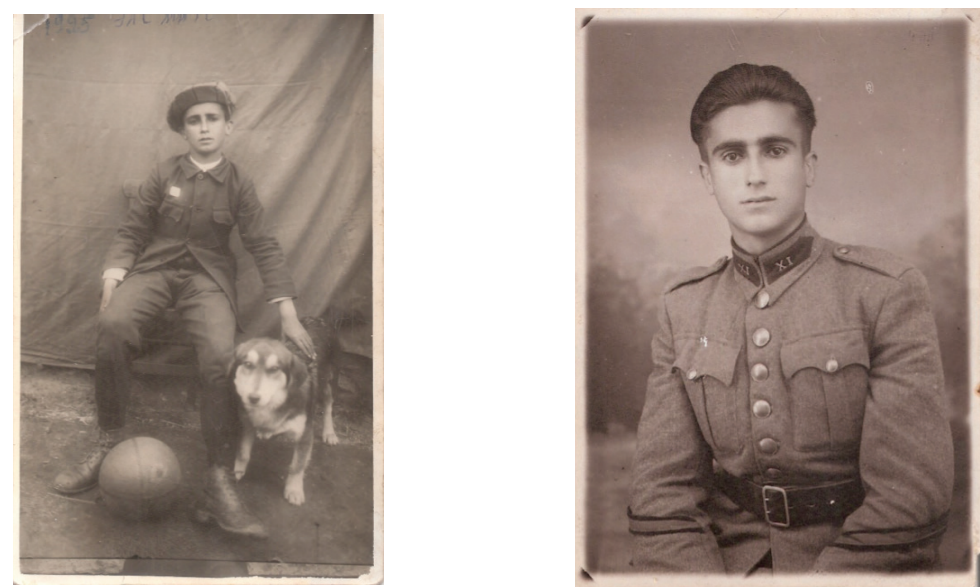

Димитар со кучето Боби - 1925 год. Димитар во војничка униформа

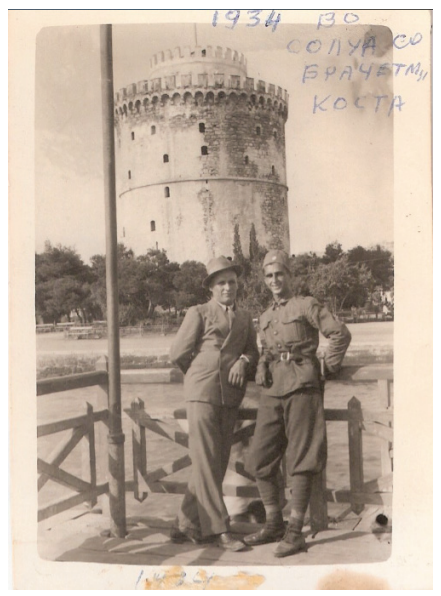

Солун- 1934 г 


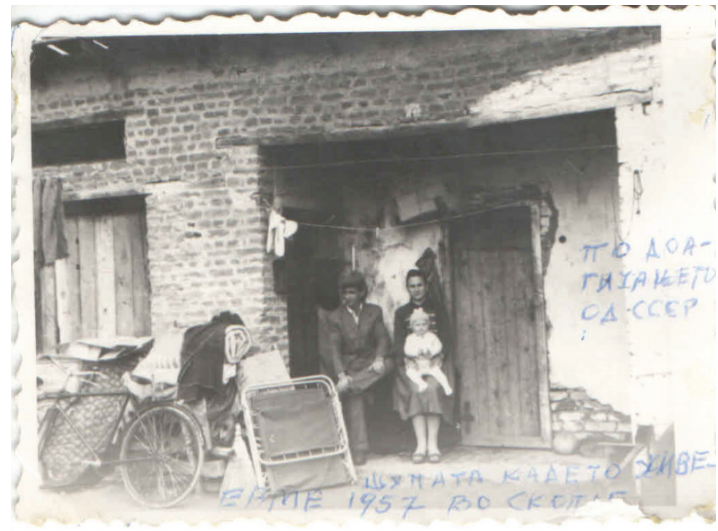

Првата куќа во Скопје - 1957 г.

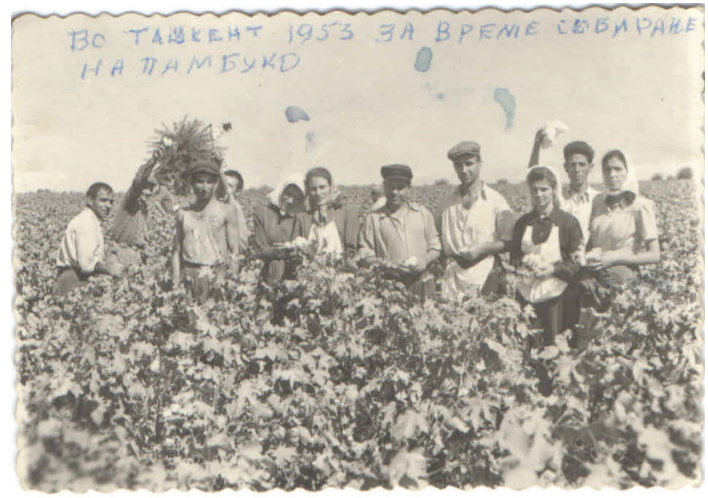

Берба на памук - Ташкент 


\section{Извор}

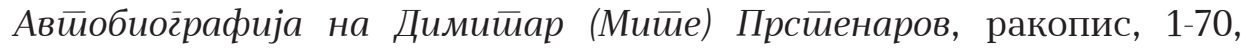
Дигитален Архив за етнолошки и натрополошки ресурси (ДЕАР), ДЕМ_1530, Институт за етнологија и антропологија, Природноматематички факултет, Универзитет „Св. Кирил и Методиј“Скопје.

\section{Литература}

Д-р Ристо Кирјазовски превод, редакција, коментар. 1996. Ег̃ејска Макеgонија во НОВ (Сейиември 1944 - Февруари 1945), Том VII Книга 3, Архив на Македонија, Скопје: Матица Македонска.

Д-р Ицо Најдовски - Перин. 2015. Макеgонско - Авсииралиски нароgен сојуз (1946 - 1958), Скопје: Универзитет „Св. Кирил и Методиј”, Институт за национална историја.

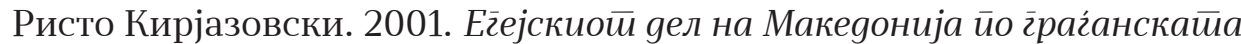
војна во Грција, Скопје: Институт за национална историја.

Главниой шӣаб на НОВ и ПОМ (1941 - 1945). Прилози од научниот собир одржан во Скопје на 19 и 20 Декември 1996, Скопје: Македонска академија на науките и уметностите, Институт за национална историја, 1997.

Џон Шеј. 2002. Макеgонија и Грција: бийкайа за дефинирање нова балканска нација, Скопје.

Exiles in the Aegean: A Personal Narrative of Greek Politics and Travel, Bert Birtles - London.

Христо Андоновски. 2017. Висӣинайа за Егеејска Макеgонија, Торонто: Risto Stefov Publications, 1938.

Марјан Марковиќ. 2007. Дијалексӣолог̄uја на Макеgонскиой јазик - 1, Скопје: Филолошки факултет „Блаже Конески”. 


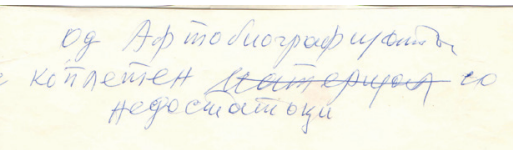

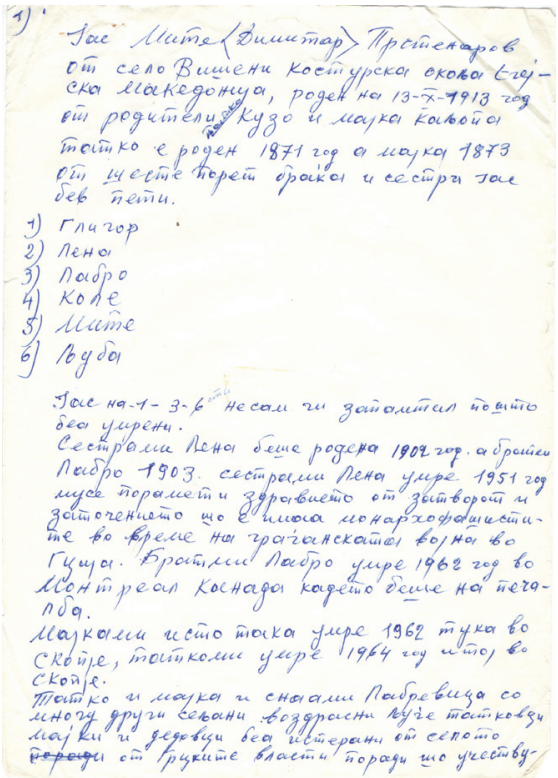

Факсимили од ракописот на Автобиографијата на Димитар (Мите) Прстенаров (1913 г. - 1996 г.) од село Вишени, Егејска Македонија 